\title{
Media Effect About Corruption News To The Community Trust on Village Performance
}

\author{
Ike Wanusmawatie \\ Department of Public Administration, Faculty of Administrative Science, University of Brawijaya \\ (email: ikew@ub.ac.id) \\ Mahandhika Hendy Firmanda \\ Alumni of Brawijaya University (email: mahandhikahendy.firmanda@gmail.com) \\ Rendra Eko Wismanu \\ Department of Public Administration, Faculty of Administrative Science, University of Brawijaya \\ (email: rendrawismanu@gmail.com)
}

\begin{abstract}
The aim of this study is to analyze the effect of media coverage on the Village Fund corruption to the community's trust regarding with village performance, especially village government. Village is sub system of local government. This research uses quantitative with explanatory method. The collecting the data uses questionnaires while, samples were 60 people. Sampling using stratified random. The study uses inferential statistical tests. Hypothesis testing is done by the coefficient of determination test; $\mathrm{f}$ test; and $\mathrm{t}$ test. Based on the results of the data obtained, it was found that there was an influence of reporting on the corruption of the Village Fund to the community trust on village government performance. The coefficient of determination test shows that the three variables of the media agenda, public agenda, and policy agenda affect the variable of village community trust by $52.7 \%$. It can be concluded that media coverage has an effect on public trust. Thus, it is strengthening the concept of the penta helix in governance. It is show at the future, the role of media taken into account in governance process.
\end{abstract}

\section{Keywords:}

governance; local government; penta helix

\section{Introduction}

The development of information and communication technology provides changes and developments to the concept of governance. It involves stakeholders, for the first time originally only three stakeholders, It called it, triple helix. Then, it evolved into a quadruple helix, and they are government, business actors, associations, and academics. In its development, the four pillars have been refined into the five pillars of stakeholders (penta helix), it consist of government, business, associations / communities, academics, and the media. The inclusion of media in the framework of government collaboration plays a role in 
strengthening the other four pillars. In this case, it plays a role in disseminating information and monitoring the performance of all stakeholders.

Besides providing ease of information, the media also has an impact. Junaedi (2018: 67) states that the media effect has three phases. One of these phases is the media has the power to form opinions and beliefs and change behavior. Meanwhile, Holilah's (2016) study concluded that mass media has a strong impact on the spread and influences people's perceptions and behavior. Previously in 2011, Rini (2011) conducted research on "The Role of Mass Media in Encouraging Social Change in Society". This research concluded that the mass media played an active and effective role in disseminating information. Thus the mass media has an impact. One of the impacts is a change in the attitude of society globally, it means the decline in community trust in the state and government. This was strengthened by Hasnawati (2018) in her research entitled "The Effect of Corruption Case Reporting on TV One on Student Perceptions of the Performance of the Corruption Eradication Commission" it concludes that the corruption news broadcast has an agenda setting effect because it raises awareness of the importance of the topic of corruption.

One of the topics is often reported and has caught public attention is corruption in government institutions, especially at the village level. This is because the Village Fund is one of the newest budgets from the $A P B N$, it is specially given by the central government to villages as regulated in Law Number 6 of 2014 concerning Villages. The case of the Fund corruption in the Detik news media on September 12, 2019, reported by the Head of Pragelan village for the 2011 to 2016 period in Bojonegoro Regency was a suspect in the village Fund corruption of Rp. 156 million in the management of the 2016 village financial budget (Rofiq, 2019). On 31 August 2019 in the media Kompas.com there was also news about the corruption of the Village Fund carried out by the Village Head of Dukuhmojo in Jombang Regency. The Village Fund was diverted was valued at Rp. 278.4 million from two activities carried out in 2018 (Gabrillin, 2019). The next report on the Village Fund corruption case was in the Antara Yogya media, namely the Head of Banyurejo Village, Sleman Regency. The Village Head corrupted the Banyurejo Village Fund for the 2015 and 2016 fiscal years. It worth IDR 633 million (Pranyoto, 2019).

The recapitulation of the Indonesian Corruption Watch (ICW) at intervals of four years (2015-2018), stated there were 181 Corruption Cases in Village Funds that caused losses to the 
state amounting to IDR 40.6 billion. The results of ICW's monitoring, from 2015 to Semester I of 2018, cases of Village Fund corruption have increased from year to year. Based on Kompas.com report, since 2015 until now, the Village Fund has been disbursed by the government is Rp. 186 Trillion. This fund has been distributed to 74,954 villages throughout Indonesia. However, in its development, the implementation of the Village Fund is prone to corruption practices (Ihsanuddin, 2018).

From the description above, it shows the corruption reporting in the media is very massive and has caught the public's attention. Given the media has an impact as has been proven by previous research, it will get worse if the level of community literacy is low, especially in rural areas. In addition it support in the form of supervision of the implementation of government affairs and village development. It can influence the attitudes and behavior of the village community to be very passive, namely decreasing the level of community trust in the performance of the village government or vice versa. Therefore this research makes mass media coverage of the case Village Fund corruption as a basis for seeing the effect of news on public trust in the performance of village government.

The hypothesis built is "There is an influence of media coverage of village fund corruption on the trust of village communities related to the performance of village government". The aim of this study is to see whether there is an influence in media coverage of village fund corruption on the trust of the village community. Furthermore, the concepts used to analyze are the concepts of Governance, Penta Helix and mass media effect.

\section{Methods}

The design of this research is dominantly quantitative research. Quantitative is found in a productive thinking pattern narrated in the background. Then there is data collection techniques that use surveys and tools in the form of questionnaires, as well as analysis using influence testing through SPSS 24 (Statistical Package for Social Sciences).

Singarimbun and Effendi (1989: 5) state that to explain the causal relationship between variables, hypothesis testing is needed, because that this research uses hypothesis testing, this research can also be called an explanatory research. The hypothesis to be tested is "There is an effect of media reporting on village fund corruption on community trust related to village government performance". The independent variables in this study are the Media Agenda 
(X1), the Public Agenda (X2), the Policy Agenda (X3) on the reporting of the Village Fund corruption case, while the dependent variable in this study is community trust regarding the performance of the Village Government $(Y)$.

The respondents of this study were the villager of Punggulrejo Village, Rengeld District, with a sample of 60 people. Sampling using a stratified random sample with the criteria: Punggulrejo Village community, aged 17-50 years, minimum high school education, and media users. The respondents consisted of 60 people, it consist of 37 people, between 17 to 25 years old; 10 people, between 26 to 34 years old; 8 people, between 35 to 42 years old; and 5 people, between 43 to 50 years old. There were 40 female respondents and 20 male respondents. Respondents who graduated from high school were 46 people; 3 D3 people; 11 people were graduated from S1 / D4. This study uses inferential statistical tests, hypothesis testing uses the coefficient of determination; $\mathrm{f}$ test; and $\mathrm{t}$ test.

\section{Results and Discussion}

\section{Effect of "Media Agenda" about Corruption News to The Community Trust on Village} Performance

Based on the results of the multiple linear regression tests, the variable "Media Agenda (X1)" Corruption News has a regression coefficient of 0.105 . This means that the variable "Media Agenda" has a relationship with the variable "Community trust". If the Media Agenda increase by $1 \%$, then community trust will increase by $10.5 \%$. Furthermore, according to the partial significance test ( $t$ test) of the Media Agenda, there is no partial influence on Community trust, this is based on the Sig. Media Agenda (0.337) $>0.05$ and the $t$ value of Media Agenda (0.968) <t table (2.004), then the Media Agenda variable (X1) partially has no effect on community trust (Y). So it can be concluded that the variable "Media Agenda" has a positive relationship with community trust but does not have a partial effect on community trust.

The relation between "Media Agenda" Corruption News and "Community Trust" is 0.105. This means that if the media increases the news about Village Fund corruption and features the news in various sources, it will make the community feel that the news is important, and make the community know and understand that the village government is prone to Village Fund corruption. If the public knows a lot of information about Village Fund corruption, the community will know the village government performance. If it is, the 
community will give reciprocity with community trust. As Mc Comb and Shaw say as quoted by Heryanto (2018: 247) in their book entitled "Political Communication Media", that the media puts pressure on an event so that the media will influence the audience to consider it important.

\section{Effect of "Public Agenda" about Corruption News to The Community Trust on Village Performance}

Based on the results of multiple linear regression tests, the variable "Public Agenda" Corruption News" has a regression coefficient value of -0.002. It means that the variable "Public Agenda" has a relation with the variable "Community trust" of -0.002 (negative relationship). If the "Public Agenda" increases by 1\%, the "Community trust" will decrease by $0.2 \%$. While according to the $t$ test (partial significance) of the "Public Agenda" Corruption News, the results obtained a $t$ value of -0.023 and a significance value of 0.982 . The magnitude of the significance value $(0.982)>0.05$ and the amount of $t$ count $(-0.023)<t$ table $(-2.004)$, it can be concluded that there is no partial effect of the variable "Public Agenda (X2)" Corruption News Village Fund on the "Community trust $(Y)$ ". So the conclusion that can be drawn, "Public Agenda" Corruption News of Village Fund" has a negative relationship with "Community trust" but does not have a partial effect on "Community trust".

The relation between "public agenda" about corruption news of Village Fund and "community trust" is -0.002. This means that if the public's awareness of news of Village Fund corruption and the public's penchant for news of Village Fund corruption increases by 1\%, then "Community trust in Village Government Performance will decrease by $0.2 \%$.

Public knows more, anticipatory, and actively monitor the performance of the Punggulrejo Village Government. They more aware of the news of the Village Fund corruption, and people of Punggulrejo Village will actively assess the performance of the Punggulrejo Village Government, if the performance is bad, the trust of the Punggulrejo Village community will decline. As the opinion of Bernard C. Cohen (Nurudin, 2007: 195) states that the Agenda Setting Theory is a theory which states that mass media acts as a center for determining truth with the ability of mass media to transfer two elements, namely awareness and information into the public agenda by directing public awareness and attention. to issues considered important by the mass media. 


\section{Effect of Policy Agenda about Corruption News to The Community Trust on Village Performance}

Based on the results of the multiple linear regression test, the variable of policy agenda on corruption news has a regression coefficient value of 0.788 . The variable that means "Policy Agenda" has a positive relation with the variable "community trust" of 0.788 . If the "policy agenda" increases by $1 \%$, then "community trust" will increase by $78 \%$. While, based on the $t$ test (partial significance) of the "policy Agenda" on corruption news, the results of the t value are 5.999 and a significance value of 0.000 . The magnitude of the significance value $(0.000)$ $<0.05$ and the amount of $\mathrm{t}$ count (5.999) $>\mathrm{t}$ table (2.004), it can be concluded that there is a partial effect of the variable "policy agenda (X3)" Corruption News of Village Fund on the variable "community trust $(\mathrm{Y})$ ". It means "policy agenda" has a positive relation with "community trust" and has a partial effect on "community trust".

The relationship between "Policy Agenda" Corruption News and "Community trust"amounted to 0.788 . This means that if the support of the village government for the publication of the Village Fund corruption increases, and the corruption eradication actions carried out by the Punggulrejo Village Government are increased, and the corruption prevention measures carried out by the Punggulrejo Village Government are also increased by 1\% each, then "Community Trust in Village Government Performance" will increase. at 78.8\%.

This shows that the community is very supportive of the prevention of corruption. Village Fund. The community feels that the role of government is very important in conducting socialization, and then it will incrase community trust.

\section{Effect of "Media, Public, and Policy Agenda" about Corruption News to The Community Trust on Village Performance}

Based on the simultaneous significance test ( $\mathrm{f}$ test), the results of the $\mathrm{f}$ count is 20.758 and a significance value is 0.000 . Based on these results the significance value $(0.000)$ is less than 0.05 and the calculated $f$ value (20.758) is greater than $f$ table (2.77), so that the three independent variables $\mathrm{X} 1, \mathrm{X} 2, \mathrm{X} 3$ (Agenda Setting) have a simultaneous effect on the variable bound (Y). The conclusions that can be drawn, the Media Agenda (X1), the Public Agenda (X2), the Policy Agenda (X3) Corruption News of Village Fund have an effect together 
(simultaneously) with the "Community trust $(\mathrm{Y})$ " regarding the performance of the Punggulrejo Village government.

The Corruption News of Village Fund by the media (agenda setting) has an influence on community trust regarding the performance of the Village government in Punggulrejo Village, Rengel District, Tuban Regency. Agenda setting is the arrangement or preparation of agendas / events / activities (Ritonga, 2018). In this study, reporting on the corruption of the Village Fund is an arrangement and arrangement of an event agenda by the media so that the public knows what the media knows. After the community learned about the Village Fund corruption, then the community felt that the news of the Village Fund corruption was important to know. It is in line with the statement of Stephen W. Littlejohn and Karen A. Foss (Baran and Dennis, 2007: 13) that in the agenda setting, the media forms an important picture or issue in the mind.

Corruption News of village fund provide information, where this information provides awareness to the community about the need for monitoring and control of the village government. Governance involves not just the government and the state, so the parties involved are very broad (Widodo, 2001: 18), and governance includes the totality of all institutions (government or non-government) and elements of society. (Dwiyanto, 2015: 1). Public control through the media is needed to smooth the running of good governance.

The normality test uses the Kolmogorov Smirnov (K-S) non-parametric statistical test, in Figure 1 shows that the residual media coverage variable is normally distributed because the Asymptotic Significance (2-tailed) value of 0.200 is greater than 0.005 . 
Figure 1.

One-Sample Kolmogorov-Smirnov Test

\begin{tabular}{|ll|r|r|r|}
\hline & $\begin{array}{c}\text { Pemberitaan } \\
\text { Media }\end{array}$ & $\begin{array}{c}\text { Kepercayaan } \\
\text { Masyarakat }\end{array}$ & $\begin{array}{c}\text { Unstandardized } \\
\text { Residual }\end{array}$ \\
\hline $\mathrm{N}$ & Mean & 60 & 60 & 60 \\
Normal & 125,12 & 38,90 & .0000000 \\
Parameters & Std. Deviation & 20,675 & 6,103 & 5.09018690 \\
Most Extreme & Absolute &, 083 &, 078 & .065 \\
Differences & Positive &, 083 &, 068 & .062 \\
& Negative &,- 077 &,- 078 & -.065 \\
Test Statistic & &, 083 &, 078 & .065 \\
Asymp. Sig. (2-tailed) & $.200^{\mathrm{c}, \mathrm{d}}$ & $.200^{\mathrm{c}, \mathrm{d}}$ & $.200^{\mathrm{c}, \mathrm{d}}$ \\
\hline
\end{tabular}

a. Test distribution is Normal.

b. Calculated from data.

c. Lilliefors Significance Correction.

d. This is a lower bound of the truw significance

Source: obtained from primary data

Multiple linear regression test in this study using SPSS 24, the results of multiple linear regression analysis in figure 2 :

Figure 2.

\begin{tabular}{|c|c|c|c|c|c|c|}
\hline \multicolumn{7}{|c|}{ Coefficients $^{n}$} \\
\hline \multirow{2}{*}{\multicolumn{2}{|c|}{ Model }} & \multicolumn{2}{|c|}{ Unstandardized Coefficients } & \multirow{2}{*}{$\begin{array}{c}\text { Standardized } \\
\text { Coefficients } \\
\text { Beta } \\
\end{array}$} & \multirow[b]{2}{*}{$\mathrm{t}$} & \multirow[b]{2}{*}{ Sig. } \\
\hline & & B & Std. Error & & & \\
\hline \multirow[t]{4}{*}{1} & (Constant) & 8.399 & 3.975 & & 2.113 & .039 \\
\hline & Agenda Media & .105 & .108 & .128 & .968 & .337 \\
\hline & Agenda Publik & -.002 & .065 & -.003 & -.023 & .982 \\
\hline & Agenda Kebijakan & .788 & .131 & .652 & 5.999 & .000 \\
\hline
\end{tabular}

Source: obtained from primary data

While the heteroscedasticity test used the Glejser test, showing the results of each variable did not experience heteroscedasticity (sig.> 0.05). In figure 3 , the details of the sig value. the media agenda variable was 0.345 ; sig value. public agenda variable of 0.824 ; sig value. the policy agenda variable is 0.524 . 
Figure 3.

Coefficients $^{\mathrm{a}}$

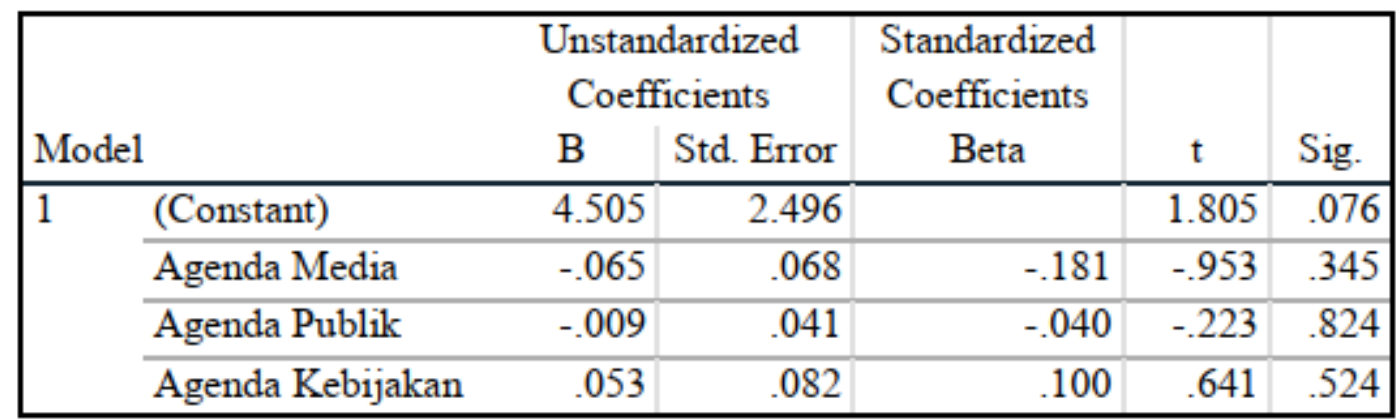

a. Dependent Variable: RES2

Source: obtained from primary data

The multicollinearity test uses the Tolerance and VIF (Variance Inflation Factor) method, the results show do not occur multicollinearity. In figure 4, the Tolerance value for "media agenda" is 0.482 (greater than 0.10 ) and the VIF value for "media agenda" is 2.074 (less than 10); Tolerance value for "public agenda" is 0.537 (greater than 0.10 ) and VIF value for "public agenda" is 1.863 (less than 10); Tolerance value for "policy agenda" is 0.716 (greater than 0.10) and VIF value for "policy agenda" is 1.397 (less than 10).

Figure 4.

\begin{tabular}{|c|c|c|c|c|c|c|c|c|c|c|c|}
\hline \multicolumn{12}{|c|}{ Coefficients $^{a}$} \\
\hline & & \multicolumn{3}{|c|}{$\begin{array}{l}\text { Unstandardized } \\
\text { Coefficients }\end{array}$} & \multirow{2}{*}{\multicolumn{2}{|c|}{$\begin{array}{c}\text { Standardized } \\
\text { Coefficients } \\
\text { Beta }\end{array}$}} & \multirow[b]{2}{*}{$\mathrm{T}$} & \multirow[b]{2}{*}{ Sig. } & \multicolumn{3}{|c|}{ Collinearity Statistics } \\
\hline \multicolumn{2}{|l|}{ Model } & B & \multicolumn{2}{|c|}{ Std. Error } & & & & & \multicolumn{2}{|c|}{ Tolerance } & VIF \\
\hline \multicolumn{2}{|c|}{1 (Constant) } & 8.399 & & 975 & & & 2.1 & .039 & & & \\
\hline \multicolumn{2}{|c|}{ Agenda Media } & .105 & & .108 & & .128 & .9 & .337 & & .482 & 2.074 \\
\hline \multicolumn{2}{|c|}{ Agenda Publik } & -.002 & & .065 & & -.003 & -.0 & .982 & & .537 & 1.863 \\
\hline \multicolumn{2}{|c|}{ Agenda Kebijakan } & .788 & & .131 & & .652 & 5.9 & .000 & & .716 & 1.397 \\
\hline \multicolumn{12}{|c|}{ a. Dependent Variable: Kepercayaan Masyarakat } \\
\hline \multicolumn{12}{|c|}{ Collinearity Diagnostics $^{a}$} \\
\hline & & & & \multirow{2}{*}{\multicolumn{2}{|c|}{$\begin{array}{l}\text { Condition } \\
\text { Index }\end{array}$}} & \multicolumn{6}{|c|}{ Variance Proportions } \\
\hline Model & Dimension & \multicolumn{2}{|c|}{ Eigenvalue } & & & \multicolumn{2}{|c|}{ (Constant) } & $\begin{array}{l}\text { Agenda } \\
\text { Media }\end{array}$ & $\begin{array}{l}\text { Agenda } \\
\text { Publik }\end{array}$ & \multicolumn{2}{|c|}{$\begin{array}{c}\text { Agenda } \\
\text { Kebijakan }\end{array}$} \\
\hline \multirow[t]{4}{*}{1} & 1 & & 3,950 & & 1,000 & &, 00 &, 00 &, 00 & &, 00 \\
\hline & 2 & & 028 & & 1,901 & &, 22 &, 02 & , 48 & &, 08 \\
\hline & 3 & & 012 & & 8,107 & & ,36 & 69 &, 46 & &, 06 \\
\hline & 4 & &, 010 & & 9,585 & &, 42 &, 29 & 06 & & 86 \\
\hline
\end{tabular}

Source: obtained from primary data 
The partial significance test $(t)$ in Figure 5 shows the variable of "media agenda" has no partial influence on the community trust variable. a significance value of 0.337 (more than 0.05 ) and $t$ count 0.968 (less than $t$ table (2.004)); the "public agenda" variable has no partial effect on the community trust variable, with a significance value of 0.982 (more than 0.05 ) and t count -0.023 (smaller than $\mathrm{t}$ table (-2.004)); the "policy agenda" variable has a partial influence on the community trust variable, with a significance value of 0.000 (less than 0.05 ) and $t$ count of 5.999 (greater than $\mathrm{t}$ table (2.004)).

Figure 5.

Coefficientsa

\begin{tabular}{|c|c|c|c|c|c|c|}
\hline \multirow{2}{*}{\multicolumn{2}{|c|}{ Model }} & \multicolumn{2}{|c|}{$\begin{array}{l}\text { Unstandardized } \\
\text { Coefficients }\end{array}$} & \multirow{2}{*}{$\begin{array}{l}\text { Standardized } \\
\text { Coefficients } \\
\text { Beta }\end{array}$} & \multirow[b]{2}{*}{$\mathrm{t}$} & \multirow[b]{2}{*}{ Sig. } \\
\hline & & B & Std. Error & & & \\
\hline 1 & (Constant) & 8.399 & 3.975 & & 2.113 & .039 \\
\hline & Agenda Media & .105 & .108 & .128 & .968 & .337 \\
\hline & Agenda Publik & -.002 & .065 & -.003 & -.023 & .982 \\
\hline & Agenda Kebijakan & .788 & .131 & .652 & 5.999 & .000 \\
\hline
\end{tabular}

a. Dependent Variable: Kepercayaan Masyarakat

Source: obtained from primary data

The simultaneous significance test $(F)$ in Figure 6 shows the results of the three variables (media agenda, public agenda, policy agenda) have a simultaneous effect on the community trust variable, with a significance value of 0.000 (less than 0.05 ) and the calculated $\mathrm{f}$ value of 20.758. (greater than $\mathrm{f}$ table (2.77)).

Figure 6.

\begin{tabular}{|c|c|c|c|c|c|c|}
\hline \multicolumn{2}{|c|}{ Model } & Sum of Squares & $\mathrm{df}$ & Mean Square & $\mathrm{F}$ & Sig. \\
\hline \multirow[t]{3}{*}{1} & Regression & 1156.988 & 3 & 385.663 & 20.758 & $.000^{6}$ \\
\hline & Residual & 1040.412 & 56 & 18.579 & & \\
\hline & Total & 2197.400 & 59 & & & \\
\hline
\end{tabular}

a. Dependent Variable: Kepercayaan Masyarakat

b. Predictors: (Constant), Agenda Kebijakan, Agenda Publik, Agenda Media

Source: obtained from primary data

The determination coefficient test ( $\mathrm{R}$ square) in Figure 6 shows the results of the Rsquare value of 0.527 so that the influence of the three independent variables (media agenda, public agenda, policy agenda) on the dependent variable (community trust) is $52.7 \%$. 
Figure 7.

\begin{tabular}{|l|c|r|r|r|}
\hline \multicolumn{5}{|c|}{ Model Summary } \\
\hline Model & R & R Square & $\begin{array}{c}\text { Adjusted } \\
\text { R Square }\end{array}$ & $\begin{array}{c}\text { Std. Error of the } \\
\text { Estimate }\end{array}$ \\
\hline 1 & $.726^{\text {a }}$ & .527 & .501 & 4.310 \\
\hline
\end{tabular}

a. Predictors: (Constant), Agenda Kebijakan, Agenda Publik, Agenda Media

Source: obtained from primary data

\section{Discussion}

Recent scholarships in public administration and legal studies have agreed on the role of public information disclosure as a necessary requirement in eradicating corruption (2020:167). Media coverage is information that has an impact on society. Morris in Fachruddin (2012: 47) states that news is something important and new, which has an impact and benefits in human life. Fachruddin (2012: 47) explains further by quoting Wahyudi's (1994) opinion that explains news as a report about events or opinions that have important value. In Indonesia, the application of Agenda Setting Theory in media coverage has a significant influence on audiences. News about the eradication of corruption is the news most frequently reported by the mass media. Such as, the news about the corruption of the Village Fund of the Former Village Head in Pragelan Village, Bojonegoro Regency in Detiknews Media, the news in Kompas Media about the corruption of the Village Fund carried out by the Village Head of Dukuhmojo in Jombang Regency, the news from AntaraYogya Media about the corruption of Village Fund for the Village Head of Banyurejo Village, Sleman Regency, etc

There are no exact definitions of the village fund. However, based on the history of the village fund, the fund can be categorized as a special allocation fund. It is reasonable, due to the village fund comes from the allocation of the Indonesian Government Budget. This is indeed different than microßinance programme which has a size of the intervention and its consequent to policy importance (Dußlo, 2004 cited by Imawan \& Putranto: 2020). The special allocation fund is diverse than the micro- $\beta$ inance programme, due to the only intention of the village fund to build the interest of the village development. (Imawan \& Putranto, 2020: 18). According this study, there is no correlation between village fund with eradicating poverty. This result is the same with Wanusmawatie study (2018) that village fund and many grant for 
village does not make less poverty but triggering to build community independence to the upper village government. Village classifying into 2 type there are recognition and created village. Both have difference on using village fund but have similarities in the absorption of funds. Village funds have not been used as expected by regulations. the community has jealousy due to the lack of transparency in the use of village funds. This has further triggered a sense of lack of trust in the village government, coupled with the reporting of corruption in the mass media.

Agenda setting according to Ritonga (2018) can be understood as an arrangement or arrangement of an agenda / event / activity. In accordance with the terms put forward by Stephen W. Littlejohn and Karen A. Foss in Baran and Dennis (2007: 13) that the Agenda Setting Theory is a theory states the media form images or issues that are important in the mind. Bernard C. Cohen (Nurudin, 2007: 195 ) states that Agenda Setting Theory is a theory which states that media massa acts as a center for determining truth with the ability of mass media to transfer two elements, they are awareness and information into the public agenda by directing public awareness and attention to issues considered important by the mass media.

Samsudin A. Rahim in Kholil (2007: 36), agenda setting is the role of mass media which has the power to influence people's opinions and behavior by determining the agenda for issues that are considered important. The application of the agenda setting in media coverage has a significant impact, especially in cases such as corruption. Then, according to Klitgaard (2001: 31) corruption as behavior that deviates from the official duties of a state office because of the benefits of status or money which are personal (individual, close family, own group); or breaking the rules for implementing some personal behavior. In general, corruption is a combination of bad intentions, harmful actions and opportunities. Corruption has a negative impact on various aspects of life, especially a sense of trust, both politically and socially. Corruption has a tremendous impact, be it economic, political, social or environmental losses. On the political side, public participation in democracy is important. Djelantik (2008) explains that there is frustration and apathy among the public as a result of public distrust which in turn causes weak civil society, weak civil society which then paves the way for depotism. 
Community trust is a very important and fundamental element to get a legitimate public administration (Mardiyanta, 2013). In the context of democratic policy, community trust becomes a determinant variable, not just an outcome variable. The high level of community trust certainly makes it easier for participants to assess the impact of the program (Wahyuningsih, 2011). Community participation is one factor to make effective government especially on village fund implementation (Arifah, 2019).

Based on the results of the research in accordance with the theories of the experts, the agenda setting news on corruption in the Village Fund has a simultaneous influence on community trust. In accordance with the results of the simultaneous significance test $(F)$, the results of the three variables (media agenda, public agenda, policy agenda) have a simultaneous effect on the community trust variable, with a significance value of 0.000 (less than 0.05 ) and a calculated $\mathrm{f}$ value of 20.758. (greater than $\mathrm{f}$ table (2.77)), and the coefficient of determination (R Square) shows the R square value of 0.527 so that the influence of the three independent variables (media agenda, public agenda, policy agenda) on the dependent variable (community trust) amounted to $52.7 \%$.

The main result based on the the analysis and interpretation of data carried out in Punggulrejo Village, Rengel District, Tuban Regency regarding the effect of reporting on Village Fund corruption by the media on public confidence regarding the performance of the Punggulrejo Village Government. With independent variables in the form of a Media Agenda (X1), a Public Agenda (X2), a Policy Agenda (X3) (Agenda Setting). The following are the results of the analysis and interpretation of the research data:

1. Media Agenda (X1). The Media Agenda has a positive relationship with Community Trust, based on multiple linear regression with a Media Agenda regression coefficient value of 0.105. However, the Media Agenda has no partial effect on Community Trust. Evidenced by partial significant test results ( $t$ test), with a significant value of $0.337>0.05$ and $t$ count of $0.968<t$ table (2.004). The conclusion is the media agenda of corruption in the Village Fund by the media does not have a partial effect on community trust in improving the performance of the Punggulrejo Village Government.

2. Public Agenda (X2). The Public Agenda has a negative relationship with Community Trust, based on multiple linear regression with a coefficient of regression of the Public 
Agenda of -0.002. However, the Public Agenda has no partial effect on Community Trust. Evidenced by partial significance test ( $t$ test), a significant value of $0.982>0.05$ and $t$ count of $-0.023<t$ table (2.004). the conclusion of the public agenda, the reporting of corruption in the Village Fund by the media does not have a partial effect on community trust in improving the performance of the Punggulrejo Village Government

3. Policy Agenda (X3). The Policy Agenda has a positive relationship with Community trust, based on multiple linear regression tests with the Policy Agenda regression coefficient value of 0.788 . The Policy Agenda has a partial effect on Community trust. Evidenced by the partial significance test ( $\mathrm{t}$ test), with a significance value of 0.000 $<0.05$ and $t$ count of 5.999 $>\mathrm{t}$ table (2.004). With the conclusion that the policy agenda of the Village Fund corruption reporting by the media has a partial effect on public confidence regarding the performance of the Punggulrejo Village Government.

4. Media Agenda (X1), Public Agenda (X2), Policy Agenda (X3) (agenda setting). Based on the simultaneous significance test ( $\mathrm{f}$ test), it was obtained $\mathrm{f}$ count of 20.758 with a significance value of 0.000 . The significance value $(0.000)<0.05$ and $f$ count (20.758)> f table (2.77), the conclusion is that the Media Agenda, Public Agenda, and Policy Agenda for the reporting of corruption in the Village Fund simultaneously (jointly) have an effect on community trust regarding the performance of the Punggulrejo Village Government.

5. Media Agenda (X1), Public Agenda (X2), and Policy Agenda (X3) have an R Square value of 0.527 . With the conclusion that the magnitude of the influence of the three independent variables (X1, X2, X3 / agenda setting) on the dependent variable (community trust) is $52.7 \%$.

Refers to the above, the practical recommendations are the community must act to increase curiosity about indications of Village Fund corruption; The community must always take the time to control the management of the Village Fund in the Punggulrejo Village Government; The village government needs to carry out socialization to provide knowledge of corruption and the Village Government must make efforts to carry out transparency in the accountability report for the management of the Village Fund. This recommendation strengthening the previous study recommendation that village does not 
"walking alone" but requiring other sub systems support such us community, local and central government (Wanusmawatie, 2018).

\section{Conclusion}

Media coverage has an influence on community and public trust in wider aspect. The media provide evaluation and control over the government and governance by reporting what is happening in government, according to its role in the concept of the penta helix. The Village Fund Corruption Case in the perspective of the agenda setting is news that the public needs to know and the media tries to provide input and emphasize that the news is important. In the perspective of public administration science, Good Governance is a must. Good governance is governance in which there is control and participation of the public, to improve governance reform and policy making.

\section{References}

Arifah, Indah Nur. (2019). Community Participation and Government Role in Using Village Funds in Dlingo Village. Journal of Policy and Governance Review. 3 (2), 171-185. doi: https://doi.org/10.30589/pgr.v3i2.129.

Baran, Stanley J. Dennis, K Devis. (2007). Teori Komunikasi Massa:Dasar, Pergolakan, dan Masa Depan. Jakarta: Salemba Humanika.

Djelantik, Sukawarsini. (2008). Korupsi, Kemiskinan, Dan Masalah Di Negara Berkembang. Jurnal Administrasi Publik, 5(1), 18-41.

Fachruddin, Andi. (2012). Dasar-Dasar Produksi Televisi. Jakarta: Kencana.

Gabrillin, Abba. (2019, Oktober 6). Jadi Tersangka Korupsi Dana Desa, Begini Cara Kades di Jombang Meraup Uang Negara. Kompas. Retrieved from https://regional.kompas.com/read/2019/08/31/09095 191/jadi-tersangka-korupaidana-desa-begini-cara-kades-di-jombang-meraup-uang

Hasnawati, Anisa. 2018. Pengaruh Pemberitaan Kasus Korupsi di TvOne terhadap Persepsi Mahasiswa mengenai Kinerja KPK. Fakultas Syariah dan Hukum. Universitas Islam Sunan Kalijaga. Yogyakarta.

Holilah, Ilah. (2016). Dampak Media Terhadap Perilaku Masyarakat. Jurnal Studi Gender dan Anak, 3(1), 103-114. 
Imawan, Satria Aji \& Erwan Agus Purwanto.(2020). Governing Village Fund in Indonesia: Is It Eradicating Poverty?. Journal of Policy and Governance Review, 4 (1), 14-27.doi: https://doi.org/10.30589/pgr.v4i1.169

Jannah, Lina Miftahul; Muhammad Yassin Sipahutar; Desy Hariati. (2020) Public Information Disclosure: Mapping the Understanding of Multiple Actors in Corruption- Prone Indonesian Provinces. Journal of Policy and Governance Review. 4 (3). 167-18. doi: https://doi.org/10.30589/pgr. v4i3.321

Kholil, S. 2007. Komunikasi Islami. Bandung: Citapustaka Media.

Klitgaard, Robert. (2001). Membasmi Korupsi. Jakarta: Yayasan Obor Indonesia.

Mardiyanta, Antun. (2013). Restore Community trust Through Deliberative Public Policy

Formulation. Jurnal of Public Science andOrganization, 20(1), 9-17.

Nurudin. (2007). Pengantar Komunikasi Massa. Jakarta: Raja Grafindo Persada.

Ritonga,Elfi Yanti. (2018). Teori Agenda Setting dalam Ilmu Komunikasi. Simbolika, 4(1), $32-41$.

Pranyoto,Victorianus Sat. (2019, Oktober 6). Kejari Sleman Menahan Kades Banyurejo Tersangka Korupsi Dana Desa. AntaraYogya. Retrieved from https://jogja.antaranews.com/berita/395566/ kejari-sleman-menahan-banyurejotersangka-korupsi-dana-desa

Rofiq, Ainur. (2019, Oktober 6). Korupsi Dana Desa, Mantan Kades di Bojonegoro Dijebloskan Penjara. Detiknews. Retrieved from https://m.detik.com/news/beritajawa-timur/d-4704308/korupsi-dana-desa-mantan-kades-di-bojonegorodijebloskan-penjara

Wahyuningsih, Rutiana Dwi. (2011). Membangun Kepercayaan Publik melalui Kebijakan Sosial Inklusif. Jurnal Ilmu Sosial dan IlmuPolitik, 15(1), 29-40.

Wanusmawatie, Ike; Supriyono, Bambang; Hakim, Luqman; Muluk, Khairul M. R.; Wismanu, Eko, Rendra. (2018). Policy Scenario for Acceleration of Village Performance System. Advances in Economics, Business and Management Research, volume 93, 106-109. doi: https://doi.org/10.2991/aicobpa-18.2019.25

Wanusmawatie, Ike; Supriyono, Bambang; Hakim, Luqman; Muluk, Khairul M. R (2018). 
Policy Change And Implementation Of New Village Regulation Based On Public Administration Perspective. International Journal of Social and Local Economic Governance (IJLEG). 4 (1), 32-43. 